spondence courses and communicating with students about their written responses. In fact, he was grading yet another set of papers in his hospital bed just weeks before his death.

Vanlandingham wrote a number of articles and other publications dealing with state and local government and the Kentucky constitution. Those articles appeared in such publications as Municipal Government, Kentucky Law Journal, William and Mary Law Review, and Northwestern University Law Review. In the profession, he wrote the book on home rule, becoming known as the "prophet of home rule" for cities. As one former student and city manager himself commented, ". . . he brought it all together, explained all the vagaries, running up the necessary storm warnings but more important, offering the keys to making the theory work. The man was a treasure for those that believe in home rule."

Vanlandingham used his professional expertise in the broader community. He conducted a number of studies for the Kentucky Legislative Research Commission and served as a member of state committees to study problems of metropolitan government in Kentucky. He also served as consultant to the Advisory Commission on Intergovernmental Relations, and to the U.S. Bureau of the Census.

But most of all he was a gentle man, one who believed that institutions at the local level best serve the community.

He is survived by his wife Joyce and their daughter and family, all of Lexington.

Karen Mingst

Donald Gross

Bradley Canon

University of Kentucky

\section{H-G. Peter Wallach}

H-G. Peter Wallach, 56, died unexpectedly in Berlin, Connecticut, on Monday evening, March $13 . \mathrm{He}$ was a professor of political science at Central Connecticut State University. Wallach also served as director of the Connecticut State University Program for European and American Studies and as an officer of CCSU's Faculty Senate.

Wallach was on sabbatical leave, working on his sixth book, devoted to leadership. In addition to his scholarship in U.S. constitutional law, he was also a widely published authority on German politics.

CCSU President John W. Shumaker said: "Wallach was a gifted teacher and a dedicated international scholar. His participation in the University's programs to mark the 300th Anniversary of German Emigration to America in 1983 led to the founding of CCSU's German Studies Council, which he chaired. $\mathrm{He}$ and his wife, Martha Kaarsberg Wallach, professor of modern languages, established the CSU Program for European and American Studies, offering summer courses in German language, culture and political systems in Rastatt, Germany. He was instrumental in helping to establish the Connecticut/BadenWurttenberg Student Exchange Program, for which CCSU coordinates exchanges for all universities of both states."

Karen C. Beyard, vice president of academic affairs at CCSU, noted that Professor Wallach "represents such a loss to our academic community because in so many ways Peter represented what is best about academe: He was a demanding but caring teacher, a scholar whose work advanced his field, a valued friend and colleague, a campus leader whose actions and influences were felt in ways that benefitted our students in general and our university as a whole. He has left us a legacy of academic and intellectual integrity.'”

New Britain Mayor Linda Blogoslawski said: "The City of New Britain has lost a true friend and supporter, who worked hard to add an important higher education ele- ment to our sister-city relationship with Rastatt, Germany. Wallach's meetings with German business people always included mention of this city and area as potential sites for expansion in the U.S. as part of CCSU's efforts to promote economic development in its international contacts."

Former State Senator Joseph H. Harper, Jr., a leading proponent of the state-to-state exchange program, recalled: "Peter Wallach was one of the finest educators I have ever known and will be remembered for his long and tireless efforts to promote joint programs between Connecticut and BadenWurttenberg."

Appointed to the CCSU's Political Science Department in 1978, Wallach received his A.B. from Kenyon College and his M.A. and Ph.D. from the University of Connecticut. Prior to coming to CCSU, he was a lecturer at UConn, an assistant professor and department chair at the University of Wisconsin-Green Bay and academic coordinator for the urban corridor consortium at the University of Wisconsin. He was a Visiting Fellow at Yale University and lectured widely in the U.S. and in Germany, where he was frequently invited to monitor federal elections. The subject of Wallach's most recent works were his studies and observations of the last separate elections held by the former East and West German states prior to reunification.

Wallach was long associated with the American Civil Liberties Union and actively participated in many professional organizations.

Wallach is survived by his wife, Martha K. Wallach; his mother, Gerda Wallach; his brother, Wendell Wallach; his sister, Amei Wallach, three stepchildren (Fred, Ray, and Tina Kaarsberg); and three grandchildren (Sasha and Eli Bugler, and Elizabeth Kaarsberg).

\section{Central Connecticut State} University 